\title{
Mentorship for young scientists
}

BOOK TITLE:

Letters to a young scientist

AUTHOR:

Edward 0. Wilson

ISBN:

0871403773

PUBLISHER:

Liveright Publishing Corporation, USD21.95

\section{PUBLISHED:}

2013

\section{REVIEW TITLE:}

Mentorship for young scientists

\section{REVIEWER:}

Michael J. Somers

\section{AFFILIATION:}

Centre for Wildlife Management, Centre for Invasion Biology, University of Pretoria, Pretoria, South Africa

\section{EMAIL:}

mjs@up.ac.za

\section{POSTAL ADDRESS:}

Centre for Wildlife Management, University of Pretoria, Private Bag X20, Hatfield 0028, South Africa

\section{HOW TO CITE:}

Somers MJ. Mentorship for young scientists. S Afr J Sci. 2013;109(9/10), Art. \#a0027, 1 page. http://dx.doi. org/10.1590/sajs.2013/a0027

(C) 2013. The Authors

Published under a Creative Commons Attribution Licence.
Edward Wilson - an entomologist, naturalist and sociobiologist - has a string of high-level awards (including two Pulitzer Prizes) ranging over more decades than most people live. Despite being a serious scholar, his writing is neither pompous nor arrogant, but guiding and gentle. From the first page of $A$ Letter to Young Scientists I knew I was going to be inspired - reading this book brought back the memory of when, as a young MSc student, I read Wilson's The Ants ${ }^{1}$, which was in itself an inspiration. The sole purpose of $A$ Letter to Young Scientists is to mentor and encourage youngsters to become scientists, just as his earlier book had inspired me.

Each chapter is written as a letter. In these letters, Wilson uses his highly successful life in science as an example to young people who may think that they do not have what it takes to be a scientist. Much of his advice goes against what is pushed by science educators today: the need for strong mathematical skills, the need of an IQ score of genius level and the need to work on the latest and most alluring topic in science. These attributes, he says, are not that useful, in fact some can be a hindrance to success. More importantly, he believes, is that aspiring scientists find passion in science and follow their passion with hard work and vigour.

The book is divided into 20 chapters in five parts. In Part I (First Passion, Then Training) Wilson discusses the importance of passion before training - a theme throughout the book. Chapter 2 (Mathematics) is perhaps the most controversial. He argues at length that a basic understanding of maths is all that is needed, so students should not give up science because they cannot do advanced maths. If a research topic requires high-level mathematics, the solution is to collaborate with a mathematician. Throughout the book Wilson gives a number of practical principles, the first two of which are to do with maths. Principle Number One is: 'It is far easier for scientists to acquire needed collaboration from mathematicians and statisticians than it is for mathematicians and statisticians to find scientists to make use of their equations', which is how he has progressed with some advanced topics in his own career. Chapter 3 (The Path to Follow) suggests young scientists should not go where the big names are working, saying there are enough topics or taxa which have not yet been studied. Youngsters should concentrate on one of these and become a world expert on it, for which they will be recognised. This approach is the one he adopted as a young scientist when there were few people working on ants. Much of what he found through his ant work was new to science, and his enthusiasm and ambition shot him to scientific fame. He argues that young scientists can still achieve this success - and I believe he is right. Many of us try work where the most famous are working when we would be far better off working on what inspires us into being creative. Here he gives his Principle Number Three which is 'March away from the sound of the guns. Observe the fray from a distance, and while you are at it, consider making your own fray.' This I can imagine is not easy for aspiring scientists to do; it certainly is not easy for older scientists, who have been pushed in particular directions by their Directors, Deans or Heads of Departments, to do.

Part II (The Creative Process) has gems of wisdom and advice arising from his discussion of 'What Science Is' (Chapter 4) and 'The Creative Process' (Chapter 5). Here he uses snippets of his career as examples of how to proceed. Chapters 6 (What it Takes) and 7 (Most Likely to Succeed) are important because in these he discusses the qualities that make it possible to succeed in science. It is not the geniuses, he argues, but rather those like himself who are smart and determined who succeed. He discusses why this is so and sets out other personal traits that increase the chances of success in science. A challenging piece of advice given here is that a 60 -hour week is what is needed for young academics to truly succeed - and he explains how this time should be used. Chapter 8 (I Never Changed) suggests we should stick at what we do in order to become the best at it, which is perhaps only possible if scientists are allowed to keep their research freedom throughout their careers.

The chapters in Part III (A Life in Science) detail aspects of Wilson's career, describing what his research grails were and how he pursued them. This information is useful for other scientists, encouraging them to think about their own grails and how best to find them. Within these chapters, Chapter 14 (Know Your Subject, Thoroughly) points out the need for 'sustained hard work' in your chosen field and the need to know it thoroughly. Too many of us perhaps do not stick to one area of science, to our disadvantage.

In Part IV (Theory and the Big Picture) he looks at 'Science as Universal Knowledge' (Chapter 15) and 'Searching for New Worlds on Earth' (Chapter 16) and points out there is still a vast amount we do not yet know. In fact, he says, there is a 'countless number of lost worlds' which are still open for exploitation. In Chapters 17 (The Making of Theories), 18 (Biological Theory on a Grand Scale) and 19 (Theory in the Real World), he explains the nature of scientific theories and how to develop them. He uses as examples the theory of pheromone communication and the theory of biogeography, both of which he helped develop.

Finally, in Chapter 20 (The Scientific Ethic), he mentors us on the 'proper behaviour in the conduct' of our research. He warns us of rivalry and jealousy in science - which all young scientists will come across at some stage. We are warned that we will make mistakes and what to do about them.

As this book reads well it will be enjoyed by most. I especially recommend it to all at school who are thinking of becoming scientists, to all undergraduate science students, and science student mentors. Wilson himself is a wonderful mentor for us all. Besides these groups for whom the book is intended I recommend it to scientists who have gone down the research path suggested to them by their old supervisors, their Head of Department, Director or Dean, rather than following their own passion. Heads of Departments, Directors and Deans could also benefit from reading this book to reflect on how they guide those, or rather give freedom to those, under their supervision to follow their passion towards happier and more productive science careers.

\section{Reference}

1. Hölldobler B, Wilson EO. The ants. Cambridge, MA. Belknap Press of Harvard University Press; 1990. http://dx.doi. org/10.1007/978-3-662-10306-7 